\title{
Infecting the Body Politic: Observations on Health Security and the "Undesirable" Immigrant
}

\author{
Polly J. Price*
}

\section{INTRODUCTION}

As this Symposium took place in late 2014, Ebola hysteria was in full sway in the United States. ${ }^{1}$ In September 2014, as the Ebola epidemic in West Africa worsened, Director of the Centers for Disease Control and Prevention Thomas Freidan warned Congress that it was "inevitable" that the Ebola virus would enter the U.S., carried unknowingly by a traveler exhibiting no symptoms. ${ }^{2}$ The prediction was realized a short time later, when an Ebola patient was admitted for hospital care in Dallas, Texas. ${ }^{3}$ The traveler from Liberia had no symptoms of Ebola before or during his international flights. ${ }^{4}$ Instead, his illness began four days after his arrival in the United States. ${ }^{5}$

A "fear factor" played a prominent role in public response to Ebola in the United States. Public health officials noted that few countries are better equipped to keep the public safe. While undeniably catastrophic in parts of West Africa, an Ebola epidemic in the U.S. remains extremely unlikely. Scientists worry more about new viruses that easily spread through the air, unlike the transmission of Ebola. Such new viruses, or mutations of old ones, could have the global reach and devastation of the Spanish influenza in 1918.

\footnotetext{
${ }^{*}$ Professor of Law and Associate Dean of Faculty, Emory University School of Law.

1. Ebola Hemorrhagic Fever - a deadly contagious virus originating in western Africa-is spread by contact with an infected patient's blood or other body fluids. It has a high mortality rate with no known cure. It is not, however, spread through the air, sharply limiting the number of persons potentially exposed. See Ebola (Ebola Virus Disease), CTRS. FOR DiSEASE CONTROL AND PREVENTION (CDC), http://www.cdc.gov/vhf/ebola/index.html (last visited May 25, 2015).

2. AFP, Ebola's Spread to U.S. is 'Inevitable' says Health Chief, TelegraPH (Aug. 8, 2014, 2:30 AM), http://www.telegraph.co.uk/news/worldnews/northamerica/usa/11020538/Ebolas-spreadto-US-is-inevitable-says-health-chief.html.

3. Cases of Ebola Diagnosed in the United States, CDC, http://www.cdc.gov/vhf/ebola/ outbreaks/2014-west-africa/united-states-imported-case.html (last updated Dec. 16, 2014).

4. Id.

5. Id.
} 
In the United States, media-fed interest in Ebola peaked immediately before the 2014 mid-term elections, dropping off markedly thereafter when no new U.S. cases appeared. ${ }^{6}$ Human fear and human reactions affect how law is made and how it is enforced. The infinitesimally small risk of an Ebola outbreak in the United States threatens to dominate both health policy and the treatment of non-citizens travelling from Ebolaaffected areas.

The theme of this Symposium-Statelessness and Belonging: Perspectives on Human Migration-provides an opportunity to place these events in a larger context and to compare two distinct grounds to exclude "undesirable" migrants. For my contribution, I provide some observations about the global governance of pandemic disease compared to the treatment of migrants with mental illness or disability who pose no threat of spreading a disease.

Sovereign nations may refuse admission to migrants who are either physically or mentally ill or disabled. Nations have commonly preferred an ideal class - the physically and mentally healthy-to the "undesirable" migrant who is unhealthy or disabled. Both exclusions are traditionally justified as a nation's prerogative to choose its membership. Nations defend exclusionary safeguards by the need to protect their citizens against contagions from the outside world. Immigrants who are physically or mentally disabled do not pose the same threat, but they may require state services and support, what U.S. immigration law terms a "public charge." Mental illness is a different category altogether, in that public safety may be an issue, in addition to the need for state welfare expenditures.

The comparison is between temporarily banning arrivals from Sierra Leone, for example, until the threat of contagion has passed, with longstanding bans on immigrants who are viewed to pose more enduring threats - a complete disqualification on mental health grounds, unrelated to the immediate protection of public health. But these latter disqualifications are still rationalized under the rubric of "health security" by the need to sustain a general level of mental as well as physical health in the public. Mental health and disability exclusions

6. Philip Bump, The Main Thing on Voters' Minds Heading Into Election Day Might Have Been Ebola, WASH. POST (Nov. 7, 2014), http://www.washingtonpost.com/blogs/the-fix/wp/2014/ 11/07/the-main-thing-on-voters-minds-heading-into-election-day-might-have-been-ebola; see also Jessica Firger, Ebola Death Toll Rises in West Africa While Americans' Interest Wanes, CBS NEWS (Jan. 8, 2015, 5:26 PM), http://www.cbsnews.com/news/ebola-death-toll-rises-in-west-africa-whileus-interest-wanes/ (providing chart comparing the number of Ebola deaths to U.S. Google trends based upon "Ebola" searches). 
focus on individual, socially undesirable characteristics, not the communicable disease of the moment. Response to the threat of contagious disease is reactive; response to mental illness is more deliberate. Immigration policy has historically taken the category of "communicable disease" into account, just as it does the category of "mental illness," even though the specific diseases (or specific identifiable types of mental illness) change over time. Thus, the nineteenth-century world worried about people with cholera or tuberculosis, ${ }^{7}$ and the twenty-first century worries about people with Ebola. But the principle of intercepting migrants with possibly contagious diseases remains the same.

I illustrate these issues by comparing the recent Ebola outbreak with the exclusion of immigrants on the basis of mental illness in the United States. A tale of two immigrants, to borrow from Dickens - one whose misfortune is physical and fleeting, and one whose misfortune is mental and enduring. Historicizing current law from a U.S. perspective sheds light on the enduring view of a polity's "undesirable" immigrant classes.

In the United States, the policy rationale for health-based exclusions is to secure the public against contagious disease, continuing a policy that goes back at least to the cholera epidemics of the nineteenth century. Implementation of this policy has often developed one step behind our understanding of contagion and prevention. But health exclusions are also designed to secure the nation against dependency for reasons of disease, especially with respect to mental illness (again continuing a policy that goes back through the earliest regulation of immigration and has developed one step, at least, behind our understanding of mental illness).

Ultimately we see health security as a manifestation of sovereignty. The nation asserts the right to govern the risks it will take (in handling Ebola patients) and the burdens it will assume (in taking on mental health dependency). The fact that neither is fool-proof, in light of the asymptomatic but infected traveler, or the mentally ill subject who can manage to enter the U.S. undetected, illustrates the limits of sovereign authority to shape the citizenry.

I place this understanding of American policy in an international public health context - the World Health Organization and Ebola. No such multinational consideration seems to have been given to mental

7. See generally Charles E. Rosenberg, The Cholera Years: The United States in 1832, 1849, AND 1866 1-9 (2d ed. 1987) (describing epidemics in the United States in the nineteenth century). 
illness, at least in terms of global standards and guidance for admission of immigrants who are considered mentally impaired in some way. These are preliminary thoughts on an expansive subject; my hope is to provide a catalyst for further development.

\section{Global Governance of CONTAGIOUS Disease IN THE CONTEXT OF MIGRATION}

Sovereign nations have nearly unconstrained authority to exclude and even to deport non-citizens on health-related grounds. As usually stated, the right of exclusion is considered to be an attribute of sovereignty and territoriality and is defended as an inherent power necessary for the self-preservation of the state. ${ }^{8}$ In other words, if a sovereign "could not exclude aliens it would be to that extent subject to the control of another power." Acceptable justifications include public safety, security, and public welfare. ${ }^{10}$ This is true even though some treaties create obligations that contradict or limit the unconstrained exercise of sovereign rights, namely, the various international human rights treaties overseen by the U.N.'s Office of the High Commissioner for Human Rights. ${ }^{11}$

Traditionally in international law, sovereign nations have exclusive authority to control and protect their borders and to exclude non-citizens from entry. As one result, we conceive of the protection of public health and welfare as measures of national security from external threats. When threatened by pandemic disease potentially carried by migrants, nations reflexively close borders. These actions worsen the problem in affected countries, leading to economic devastation as well as disregard for the human rights of non-citizens. ${ }^{12}$ Migrants who are feared to carry a

8. See James A. R. Nafziger, The General Admission of Aliens Under International Law, 77 AM. J. INT'L L. 804, 804 (1983) (challenging the claimed right of exclusion on several grounds). The Supreme Court of the United States first endorsed this view in the late nineteenth century. See Sarah H. Cleveland, Powers Inherent in Sovereignty: Indians, Aliens, Territories, and the Nineteenth Century Origins of Plenary Power over Foreign Affairs, 81 TEX. L. REV. 1, 10-11 (2002) (noting that, in the late nineteenth century, the Supreme Court repeatedly asserted the doctrine of inherent powers "over immigrants in entry and exclusion proceedings").

9. Chae Chan Ping v. United States, 130 U.S. 581, 604 (1889).

10. See Nafziger, supra note 8, at 804-05.

11. For an overview of related treaties and the role of the U.N.'s Human Rights Commission, see International Human Rights Law, UnITED NATIONS OFFICE OF THE High COMM'R FOR HuMAN RIGHTS, http://www.ohchr.org/EN/ProfessionalInterest/Pages/InternationalLaw.aspx (last visited May 25, 2015).

12. A comprehensive examination of health law in the international context is provided in Professor Lawrence O. Gostin's seminal work in this field. See Lawrence O. Gostin, Global HEALTH LAW (2014). 
contagious disease are subject to travel bans, exclusion at borders, and visa suspensions. If they are stateless, their problems are compounded because no nation is obligated to receive them.

The Ebola outbreak in western Africa exposed weaknesses in international law for the protection of migrants. ${ }^{13}$ Political leaders in nations threatened by spread of the disease calculate self-interest ahead of any treaty obligations for movement of persons and commercial goods. Nations must balance international trade, health security, and human rights, with non-citizen migrants ending up on the far edge of the balance. The recent experience with the 2014 Ebola outbreak provides context for global governance and national regulation of citizenship and migration. ${ }^{14}$ The global public health structure draws upon sources different from the traditional principles of sovereign border control as well as from a variety of governing bodies, including the World Bank and the World Trade Organization in addition to the World Health Organization.

\section{A. Containing the Spread of Ebola}

Control of Ebola and other contagious disease is, first of all, a matter of each nation's quarantine and isolation laws as well as its public health infrastructure and capability. The World Health Organization and U.S. health officials have emphasized the need to control the epidemic in West Africa as the best defense against further spread to other nations.

13. For a critique of the global structure in earlier contexts, see Paul Arshagouni, An Introduction to Medical Issues Posed by International Health Threats in a Legal Framework, 12 Mich. ST. J. InT'L L. 199, 201-06 (2004) (SARS), as well as Nancy E. Allin, The AIDS Pandemic: International Travel and Immigration Restrictions and the World Health Organization's Response, 28 VA. J. INT'L L. 1043, 1045 (1988) (HIV/AIDS).

14. Persons seeking asylum, those who are stateless, and refugee populations present a different set of legal issues and rights as a specially protected class. For example, the U.N. High Commission on Refugees includes health directives for refugee populations, which countries typically accept as a group. For refugee populations, the U.S. provides health screening prior to entry. These issues are beyond the scope of this article, but are of great interest to scholars. See, e.g., Eleanor Acer \& Jake Goodman, Reaffirming Rights: Human Rights Protections of Migrants, Asylum Seekers, and Refugees in Immigration Detention, 24 GeO. IMMIGR. L.J. 507, 507 (2010) (describing "an increasingly acute need for States and the international community to devote greater attention and commitment to upholding the human rights of migrants"); WORLD HEALTH ORGANIZATION [WHO], Health of Migrants-The Way Forward: Report of a Global Consultation (Mar. 3-5, 2010), http://www.who.int/hac/events/consultation_report_health_migrants_colour_web.pdf; Patricia C. Gunn, Health Care Refugees, 6 LOY. U. CHI. INT'L L. REV. 339, 339 (2009) (urging developed nations to "consider giving special humanitarian protection to a new class of refugees: the "health care refugee."”). 
Experts agree that low isolation and treatment capability in the most affected nations has slowed containment of the disease. ${ }^{15}$

In unprecedented action, the United Nations Security Council characterized the Ebola outbreak as a "threat to international peace and security" and called on Member States to lift travel and border restrictions. ${ }^{16}$ The United Nations (U.N.) also established the first-ever emergency health mission, the U.N. Mission for Ebola Emergency Response (UNMEER), after the unanimous adoption of General Assembly and Security Council resolutions. ${ }^{17}$ The only other time that the U.N. Security Council addressed infectious disease was a 2011 resolution concerning HIV/AIDS. ${ }^{18}$

The transfer in September of two patients from Liberia to Emory University Hospital in Atlanta, Georgia, marked the first time the disease entered U.S. territory. ${ }^{19}$ Some public reaction was decidedly negative, including bomb threats in response to the hospital's decision to accept the patients. ${ }^{20}$ Subsequently, several other medical workers infected with Ebola were evacuated from West Africa for treatment in the U.S. To date, none of the many health and transport workers involved with these planned medical evacuations developed symptoms of Ebola.

In the case of Ebola, the potential incubation period is up to 21 days after exposure to an infected person's body fluids, and there is as yet no test to predict whether a person exposed to the disease will go on to develop symptoms. ${ }^{21}$ Surveillance, screening and contact tracing are critical to the containment of any contagious disease. These public health tools are employed to trace contacts of persons who may have

15. Adam Nossiter, Lax Quarantine Undercuts Ebola Fight in Africa, N.Y. TiMES (Aug. 4, 2014), http://www.nytimes.com/2014/08/05/world/africa/lax-quarantine-undercuts-ebola-fight-in-af rica.html.

16. See Gian Luca Burci \& Jakob Quirin, Ebola, WHO, and the United Nations: Convergence of Global Public Health and International Peace and Security, 18 ASIL INSIGHTS 25 (2014), http://www.asil.org/insights/volume/18/issue/25/ebola-who-and-united-nations-convergence-globalpublic-health-and.

17. See Press Release, Security Council, With Spread of Ebola Outpacing Response, Security Council Adopts Resolution 2177 (2014) Urging Immediate Action, End to Isolation of Affected States, U.N. Press Release SC/11566 (Sept. 18, 2014), available at http://www.un.org/ press/en/2014/sc11566.doc.htm.

18. S.C. Res. 1983, U.N. Doc. S/RES/1983 (June 7, 2011), http://www.unaids.org/sites/default/ files/sub_landing/files/20110607_UNSC-Resolution1983.pdf.

19. See Polly J. Price, Ebola and the Law in the United States: A Short Guide to Public Health Authority and Practical Limits, Emory Legal Studies Research Paper No. 14-299 (Dec. 14, 2014), available at $\mathrm{http}: / / \mathrm{ssrn} . \mathrm{com} / \mathrm{abstract}=2538187$.

20. See id.

21. Ebola (Ebola Virus Disease), Diagnosis, CDC, http://www.cdc.gov/vhf/ebola/ diagnosis/index.html (last visited May 25, 2015). 
been exposed to contagious disease. Health officials investigate personal contacts and identify others who may have been exposed in transit and during medical treatment. These persons are notified of potential exposure, provided with information and health resources, and, as appropriate, are quarantined or monitored for symptoms of the disease. ${ }^{22}$ Cross-border coordination is especially difficult.

Following the Ebola outbreak, the International Organization for Migration (IOM) turned its attention to border management in public health emergencies that threaten the well-being of migrants. ${ }^{23}$ As a starting point, the organization planned "to step up its support for building cross-border public health capacity and safe migration systems in West Africa to contain Ebola and other infectious diseases." ${ }^{24}$ This capacity is essential to migrant health as it also facilitates movement across national borders:

[T] raditional verification of medical records, history of risk exposure, and the detection of symptoms is insufficient, when informal crossborder trade, transnational communities, and porous borders exist .... Regional human mobility can perpetuate cross-border transmission, while at the same time the reopening of borders is essential for the resilience and eventual economic recovery of the affected countries. IOM's approach to health and border management ... aims to step up the prevention, detection and response to infectious diseases at points of origin, transit, destination and return. ${ }^{25}$

The public health practices IOM aims to strengthen are among the most difficult to accomplish in the context of immigration: "[V]erification of medical records, history of risk exposure, and the detection of symptoms is insufficient, when informal cross-border trade, transnational communities, and porous borders exist." 26

An underlying problem is that there is no "right to travel" between nations, and no state or international organization must insure that an unhealthy migrant can move from place to place. Realistically,

22. Interim U.S. Guidance for Monitoring and Movement of Persons with Potential Ebola Virus Exposure, CDC, http://www.cdc.gov/vhf/ebola/pdf/monitoring-and-movement.pdf (last updated Dec. 24, 2014)

23. See IOM Builds Public Health, Border Management Capacity in Ebola-Impacted Region, INT'L ORG. FOR MIGRATION (Jan. 27, 2015), http://www.iom.int/cms/en/sites/iom/home/news-andviews/press-briefing-notes/pbn-2015/pbn-listing/iom-builds-public-health-border.html.

24. $I d$.

25. Id.

26. Id.; see also Polly J. Price, Citizenship, Sovereignty, and the Protection of Public Health, 17 N.Y.U. J. LEGIS. \& PUB. POL'Y (forthcoming 2014) (detailing cross-border public health control measures in the context of immigration at the U.S.-Mexico border). 
protecting migrant health relies on diplomacy and cooperation along with the assistance of non-governmental organizations (NGOs) and publicprivate partnerships. This diplomatic role and the coordination of aid and intervention is the primary function of the World Health Organization. $^{27}$ A brief overview of the World Health Organization's mandate and capabilities provides context for the admission of noncitizens across national boundaries.

\section{B. The World Health Organization, Travel Restrictions, and Border Closures}

Global governance of disease is a directive of the World Health Organization (WHO), based in Geneva. On August 8, 2014, WHO declared the Ebola outbreak in western Africa to be an international public health emergency. ${ }^{28}$ This meant that the International Health Regulations (IHR), adopted in 2007 to address significant contagious disease, apply to political, diplomatic, and trade relationships among 194 countries across the globe, including all the Member States of WHO, in the context of matters affecting or affected by Ebola. ${ }^{29}$ The IHR are designed "to help the international community prevent and respond to acute public health risks that have the potential to cross borders and threaten people worldwide." 30 This action is only the third time WHO has declared a global health emergency. ${ }^{31}$

What response is required when WHO declares a "public health emergency of international concern," the triggering language for application of the IHR? Primarily, the IHR provide a framework for global response designed to strengthen international public health security. WHO issues recommendations that include recommended treatment and containment measures for the nations most affected by an

27. For a discussion of global governance and the protection of human rights, see Maryam Zarnegar Deloffre, Human Security in the Age of Ebola: Towards People-Centered Global Governance, E-INT'L RELATIONS (Oct. 25, 2014), http://www.e-ir.info/2014/10/25/human-securityin-the-age-of-ebola-towards-people-centered-global-governance.

28. Six Months After the Ebola Outbreak was Declared: What Happens When a Deadly Virus Hits the Destitute?, WHO, http://www.who.int/csr/disease/ebola/ebola-6-months/en/ (last visited May 25, 2015).

29. Frequently Asked Questions about the International Health Regulations (2005), WHO, http://www.who.int/ihr/about/FAQ2009.pdf.

30. International Health Regulations, WHO, http://www.who.int/topics/international_health regulations/en/.

31. Alan Cowell \& Nick Cumming-Bruce, U.N. Agency Calls Ebola Outbreak an International Health Emergency, N.Y. TIMES (Aug. 8, 2014), http://www.nytimes.com/2014/08/09/world/africa/ who-declares-ebola-in-west-africa-a-health-emergency.html. 
outbreak as well as by other threatened states. Recommended measures could be directed toward persons, cargo, ships, aircraft, road vehicles, and commercial goods.

In past outbreaks, WHO has recommended some travel restrictions, as was the case in 2009 with H1N1 influenza. ${ }^{32}$ But many nations prohibited any incoming travel from affected countries, revealing the weakness of international law with respect to WHO's mandate. Although WHO's recommendations for the Ebola outbreak did not include international travel restrictions to and from the affected regions, the declaration urged all nations where the disease is spreading to "screen all people leaving at international airports, seaports and land crossings, and to prevent travel by anyone suspected of having the Ebola virus." 33

WHO's recommended guidance included the following:

Where extraordinary supplemental measures such as quarantine are considered necessary in States with intense and widespread transmission, States should ensure that they are proportionate and evidence-based, and that accurate information, essential services and commodities, including food and water, are provided to the affected populations. ${ }^{34}$

\section{WHO also stated:}

Flight cancellations and other travel restrictions continue to isolate affected countries resulting in detrimental economic consequences, and hinder relief and response efforts risking further international spread of the disease; the Committee strongly reiterated that there should be no general ban on international travel or trade, except for the restrictions outlined in the previous recommendations regarding the travel of EVD [Ebola Virus Disease] cases and contacts. ${ }^{35}$

WHO declared that there should be no international travel of persons with Ebola or those in close contact with them, unless the travel is part of an "appropriate medical evacuation." 36 The balance is a precarious one.

32. See Rebecca Katz, Use of Revised International Health Regulations during Influenza A (H1N1) Epidemic, 2009, 15 EMERGING INFECTIOUS DiSEASES 1165, 1168 (Aug. 2009), http://www nc.cdc.gov/eid/article/15/8/pdfs/09-0665.pdf.

33. Cowell \& Cumming-Bruce, supra note 31 .

34. Statement on the 2nd Meeting of the IHR Emergency Committee Regarding the 2014 Ebola Outbreak in West Africa, WHO (Sept. 22, 2014), http://www.who.int/mediacentre/news/state ments/2014/ebola-2nd-ihr-meeting/en/.

35. Id.

36. See id 
On the one hand, WHO calls for preventing afflicted persons from traveling; on the other hand, they implore against flight cancellations and other travel restrictions. The underlying point is that restrictions should be applied only to people suffering from the disease, or likely carriers, and not to regions or nations as a whole.

Most critically, WHO warned against "geographic quarantine"sealing off a location to prevent people from leaving that area. A geographic quarantine might be used, for example, to separate a group of persons who may have been exposed to a disease until it can be determined that they are not ill. Both geographic quarantines and border closings occurred anyway. As reported in Liberia, the attempt to cordon off a large slum in the capital led to panic and violent repression of persons trying to escape. ${ }^{37}$ Residents, understandably, believed that the government had imposed a death sentence on them. In addition, five African countries shut their borders with each other, further hampering international aid.

WHO admitted shortcomings in its initial response to Ebola, based in part on its governance structure and lack of funds. Lessons learned led to a number of reform measures within WHO. ${ }^{38}$ Although these measures will not insure compliance of nations with the IHR, WHO will improve its response capacity as well as maintain a contingency fund for future public health emergencies. ${ }^{39}$ But WHO also stressed "the importance of evidence-based responses and community engagement to prevent fear, stigma and discrimination," and it reaffirmed "the enjoyment of the highest attainable standard of health is one of the fundamental rights of every human being." 40

WHO Member States agreed upon the IHR by consensus as a balance between their sovereign rights and a shared commitment to prevent the international spread of disease. Although the IHR do not include an enforcement mechanism for States that fail to comply with WHO recommendations, the potential consequences of non-compliance

37. Norimitsu Onishi, Quarantine for Ebola Lifted in Liberia Slum, N.Y. TIMES (Aug. 29, 2014), http://www.nytimes.com/2014/08/30/world/africa/quarantine-for-ebola-lifted-in-liberia-slum. html?_r=0.

38. See Stephanie Nebehey, After Ebola, WHO to Set Up Contingency Fund, Develop "Surge Capacity, "REUTERS (Jan. 27, 2015, 3:33 PM), http://www.reuters.com/article/2015/01/27/us-healthebola-who-idUSKBNOL02M020150127.

39. See id.

40. Ebola: Ending the Current Outbreak, Strengthening Global Preparedness and Ensuring WHO Capacity to Prepare for and Respond to Future Large-Scale Outbreaks and Emergencies with Health Consequences, WHO, ๆ PP2, I PP3 (Jan. 25, 2015), http://apps.who.int/ gb/ebwha/pdf_files/EBSS3/EBSS3_CONF1Rev1-en.pdf. 
are themselves a powerful tool. These consequences may include a tarnished international image, increased morbidity/mortality in affected populations, unilateral travel and trade restrictions by other nations, and economic and social disruption. Working with WHO to control a public health event such as Ebola can help prevent reflexive, unnecessary, and counter-productive border closings and economic disruption. ${ }^{41}$

Thus, "law" as we traditionally view it does not control how nations deal with each other in the event of a pandemic health threat. The IHR, however, are binding on Member States, even as they emphasize coordination and voluntary cooperation. ${ }^{42}$ The aim is to avoid overreactions that could have severe humanitarian consequences. But there is no coercion to direct at noncompliant states in the legal sense - the real bargaining tools are incentives, diplomacy, and most importantly perhaps, money. How nations react to the threat of pandemic disease, then, is never solely about science, but what has been termed "disease diplomacy." 43

\section{Mental Illness is Different?}

Sovereignty, citizenship, and migration in relation to public health are most commonly linked to contagious disease. The recent experience with Ebola underscores broader points about the treatment of noncitizens attempting to cross borders in other situations, including fleeing from armed conflict and natural disasters. ${ }^{44}$

In comparison with the threat of contagious disease as a reason to reject an applicant for admission across a national border, mental health disability exclusions are different in several respects. Unlike migration in public health emergencies, there is no international governing body to address discrimination against migrants who suffer from psychiatric disorders or limited mental capacity. ${ }^{45}$ Migration itself is stressful, of

41. See Gostin, supra note 12, at 89-128.

42. See supra note 29 and accompanying text.

43. See David P. Fidler, The Return of "Microbialpolitik": As Infectious Diseases Become a Global Threat, Policymakers Relearn an Old Lesson, ForeIGN POLICY (Nov. 20, 2009), $\mathrm{http} / / /$ foreignpolicy.com/2009/11/20/the-return-of-microbialpolitik.

44. See generally Sanjula Weerasinghe et al., On the Margins: Noncitizens Caught in Countries Experiencing Violence, Conflict and Disaster, 3 J. ON MigRATION \& HUM. SEC. 26 (2015), available at http://jmhs.cmsny.org/index.php/jmhs/article/view/42 (discussing the hardships of non-citizens caught in disaster or conflict).

45. For an overview of mental health law in a global context, see Lawrence O. Gostin \& Lance Gable, The Human Rights of Persons with Mental Disabilities: A Global Perspective on the Application of Human Rights Principles to Mental Health, 63 MD. L. REV. 20 (2004). 
course, and can lead to mental disorders. ${ }^{46}$ Historically and today, nations have excluded immigrants with mental illness or disability, making sound mental health a formal requirement of immigration law. ${ }^{47}$

Distinguishing the "desirable" from the "undesirable" immigrant is expressed in many ways and in many countries. As a general rule, western nations prefer educated professionals and persons with skills to fill employment needs. Canada, for example, recently amended its immigration laws to prioritize skilled workers and individual investors. ${ }^{48}$ The United States also privileges education and wealth. These policies contribute to a global "brain drain" from poor to rich countries. ${ }^{49}$

The opposite of the brain drain phenomenon is exclusion of migrants based upon mental capacity or psychiatric disorders. I examine these more fully in the context of the United States. At this point, however, it is useful to glance at international norms specific to the treatment of migrants with psychiatric disorders and mental disability, considered from a human rights perspective to be among the groups most discriminated against. ${ }^{50}$

The United Nations Commission on Human Rights has included the treatment of disabled persons as part of its mission for several decades. ${ }^{51}$ With respect to mental disability, the Commission identifies mentally ill persons as "particularly vulnerable," and outlines specific measures states should employ to protect them. ${ }^{52}$ But these goals apply only to persons already within a nation's boundaries. No guidance, statement of best practices, or international norms applies to the decision to admit.

46. See Dinesh Bugra \& Peter Jones, Migration and Mental Illness, 7 ADVANCES IN PSYCHIATRIC TREATMENT 216, 216 (2001).

47. See, e.g., The Multi-Ethnic Association for the Integration of Persons with Disabilities, NGO Quebec_Canada, Disability + Immigration: A New Planetary Reality (presented at the U.N. World Conference Against Racism, Racial Discrimination, Xenophobia and Related Intolerance (WCAR), Durban, South Africa, September 2001), http://www.un.org/esa/socdev/enable/rights/ ahc5docs/ahc5multiethnic.doc (providing examples from various countries).

48. See Susan Mas, 60 Millionaire Immigrant Investors to be Offered Permanent Residency, CBC NEWS (Jan. 27, 2015, 11:27 PM), http:/www.cbc.ca/news/politics/60-millionaire-immigrantinvestors-to-be-offered-permanent-residency-1.2932616; Stephanie Levitz, Canada's New 'Express Entry’ Immigration System Coming in 2015, Huffington Post (Mar. 1, 2015, 5:59 AM), http://www.huffingtonpost.ca/2014/12/30/canada-express-entry-immigration_n_6397294.html.

49. See Anup Shah, Brain Drain of Workers from Poor to Rich Countries, GLOBAL IsSUES (April 14, 2006), http://www.globalissues.org/article/599/brain-drain-of-workers-from-poor-to-richcountries.

50. See Leandro Despouy, Human Rights and Disabled Persons, UniTED NATIONS SuBCOMM'N ON PREVENTION OF DISCRIMINATION AND PROT. OF MiNORITIES \ 193, http://www.un.org/esa/socdev/enable/dispaperdes0.htm (last visited May 25, 2015).

51. Id. at 9 .

52. Id. at $\uparrow$ 193-94, 200-03. 
A 1989 report commissioned by the U.N. emphasizes how mentally disabled persons should be treated within member nations. ${ }^{53}$ Exclusion of mentally ill migrants, however, remains within national prerogative, even as nations are urged to consider restrictive immigration practices within the framework of human rights:

In the legal sphere ... many instances of discrimination can be found in immigration laws. Many national laws prevent mentally handicapped persons from entering the country, not only as permanent residents, but even as tourists, for a limited period of time. Attention is drawn to the fact that it is in the most developed Western countries (Canada, France, Switzerland, United States) that this type of restrictive legislation is most frequently applied on the grounds, in many cases, that the presence of mentally handicapped persons from abroad will impose "excessive demands on health or social services."

In addition, in 1982 the U.N. General Assembly approved a "World Programme of Action Concerning Disabled Persons." resolution, as well, centered on treatment of disabled persons within national borders: "The World Programme of Action (WPA) is a global strategy to enhance disability prevention, rehabilitation and equalization of opportunities, which pertains to full participation of persons with disabilities in social life and national development."

Regional treaties also address human rights of disabled persons, including those disabled by mental disease. The European Convention for Human Rights, for example, expressly protects mentally impaired persons in several provisions, and the European Court of Human Rights has extensive case-law developing these mental health protections. ${ }^{57}$ The court recently provided a fact sheet specifically devoted to mental health, describing relevant provisions of the Convention and the court's decisions. ${ }^{58}$

A central provision of the European Convention for Human Rights, however, also illustrates the conflation of contagious disease and mental illness as threats to the public:

53. Id. at 9194.

54. Id.

55. G.A. Res. 37/52, U.N. GAOR, 47th Sess., Supp. No. 51, U.N. Doc. A/37/51 (Dec. 3, 1982), http://www.un.org/disabilities/default.asp?id=23.

56. Id.

57. Gostin \& Gable, supra note 45 , at 57.

58. European Court of Human Rights, Fact Sheet-Mental Health (May 2013), http://www.echr.coe.int/Documents/FS_Mental_health_ENG.pdf. 
Article $5 \S 1$ : Right to liberty and security

Everyone has the right to liberty and security of person. No one shall be deprived of his liberty save in the following cases and in accordance with a procedure prescribed by law:

(e) the lawful detention of persons for the prevention of the spreading of infectious diseases, of persons of unsound mind, alcoholics or drug addicts or vagrants.

"Unsound mind," according to the court, is a term that cannot "be given a definitive interpretation:... it is a term whose meaning is continually evolving as research in psychiatry progresses, an increasing flexibility in treatment is developing and society's attitude to mental illness changes ..." c, citing the language from a 1979 decision. ${ }^{60}$ This flexibility and evolution suggest that the "mental illness" category is not any more fixed and unchanging than the "contagious disease" category, where the label on the disorder may vary but the principles by which the sufferer is handled do not.

Mental health rights in the Americas are also recognized and supported through the Inter-American Commission on Human Rights ${ }^{61}$ as well as the Pan American Health Organization (PAHO), a regional office of the World Health Organization. ${ }^{62}$ PAHO initiated the Caracas Declaration of 1990, which committed nations to improve mental health services and policies and to safeguard human rights in the region. ${ }^{63}$ Endorsed by all countries of the Americas, the Caracas Declaration aimed to improve mental health care through the replacement of the service model based on the psychiatric hospital with community alternatives of care, and through actions to safeguard the human rights of persons affected by mental disorders. ${ }^{64}$ The Caracas Declaration has

59. Id. at 3 .

60. Winterwerp v. Netherlands, Eur. Ct. H.R. (Application no. 6301/73) (1979), available at http://hudoc.echr.coe.int/sites/eng/pages/search.aspx?i=001-57597.

61. See Inter-American Commission on Human Rights, ORG. OF AMER. STATES, http://www.oas.org/en/iachr/mandate/what.asp (last visited May 25, 2015).

62. See About PAHO, PAN AMER. HeALTH ORG., http://www.paho.org/hq/index.php?option= com_content\&view=article\&id=91\&Itemid=220\&lang=en (last visited May 25, 2015).

63. The text of the Caracas Declaration is available at Mental Health Project, Mandates and Declarations, PAN AMER. HEALTH ORG., http://www.paho.org/hq/index.php?option=com content\&view=category\&layout=blog\&id=1167\&Itemid=938 (last visited May 25, 2015).

64. See The Brazilia Principles, PAN AMER. HEALTH ORG., available at http://www.paho.org/hq/index.php?option=com_docman\&task=doc_download\&gid=544\&Itemid= (last visited Mar. 31, 2015). 
been used by the Inter-American Commission of Human Rights (IACHR) as a standard of interpretation of the American Convention on Human Rights and other legal instruments. ${ }^{65}$

In 2009, PAHO adopted a ten-year "Strategy and Plan of Action on Mental Health." 66 The document generally focuses on the following "principles and values:"

a) Universality, access, and inclusion.

b) Equity in mental health.

c) Pan American solidarity, understood as collaboration among countries.

d) Respect for the fundamental human rights of people with mental disorders.

$\cdots$

f) Use of the best available scientific evidence.

g) Additional protection on mental health matters for vulnerable groups.

...

i) Mental health as a component of comprehensive health care. ${ }^{67}$

PAHO's Mental Health Project is housed in the organization's Department of Non-communicable Diseases and Mental Health, with the mission to promote and coordinate activities to strengthen the mental health systems of nations in the Americas. ${ }^{68}$

Despite substantial global attention to mental health issues, led by WHO and regional agencies, none of the directives or resolutions addresses a nation's decision to exclude non-citizens on mental health

65. Id.

66. Newsletter, Strategy and Plan of Action on Mental Health, PAN AMER. HeAlth OrG., http://www.paho.org/bulletins/index.php?option=com_content\&view=article\&id=604:strategy-andplan-of-action-on-mental-health\&Itemid=0\&lang=en (last visited Mar. 31, 2015).

67. Framework for the Implementation of the Regional Strategy for Mental Health, PAN AMER. HEALTH ORG. 5-9 (2011), http://www.paho.org/hq/dmdocuments/FRAMEWORK\%20Mental $\% 20$ Health\%20Panama.pdf?ua=1 (last visited May 25, 2015).

68. Mental Health Project, PAN AMER. HeALtH ORG., http://www.paho.org/hq/index.php? option=com_content\&view=category\&layout=blog\&id=1167\&Itemid=938 (last visited May 25, 2015). 
grounds, and migration is not considered a fundamental human right. (Conversely, nations do not categorically limit the departure of the mentally ill or disabled.) Global governance and international norms aim to protect disabled and mentally ill persons within national borders, including refugee populations, but do not include individual migrants seeking admission to a particular nation. The contrast with world governance structures directed toward contagious diseases, such as Ebola, is one of urgency or expediency rather than principle. To illustrate these points in a concrete way, I turn now to immigration laws and practices of the United States.

\section{NON-CONTAgIOUS HEALTH CONDITIONS: PSYCHIATRIC CRITERIA IN U.S. IMMIGRATION LAW}

Over the course of the twentieth century (and continuing today), immigrant health-based exclusions in the United States were linked to poverty and the likelihood that a non-citizen might become a public charge. As is the case in many other developed nations, health-based exclusions have been part of U.S. immigration law for over a century. ${ }^{69}$ These immigration restrictions served two functions: preventing importation of disease, and weeding out "undesirables.",

At several points in U.S. history, immigrants have been publicly identified as a source of contagious disease. ${ }^{71}$ There are a number of excellent scholarly works elucidating public perception of immigrants and contagious disease in the United States. ${ }^{72}$ Some have also addressed disability, including mental capacity-most notably Mark Weber's recent work on disability in U.S. immigration law. ${ }^{73}$ But psychiatric disorders merit separate consideration because, like contagious disease,

69. See Immigration Act of 1891, Ch. 551, 26 Stat. 1084, 1084 (1891) (permitting the exclusion of foreign nationals on the basis of health or communicable disease and other characteristics).

70. See generally Jennifer M. Chaćon, The Mercer Girls Guide to Immigration 64 VAND. L. REV. EN BANC 15, 18 (2011) (noting the lengthy history of immigrant exclusions based on undesirable group characteristics).

71. See, e.g., Felice Batlan, Law in the Time of Cholera: Disease, State Power, and Quarantines Past and Future, 80 TEMP. L. REV. 53, 62 (2007) (documenting response to cholera outbreaks).

72. See, e.g., Alan Kraut, Silent Travelers: Germs and the Immigrant Menace (1995); Howard Markel \& Alexandra Minna Stern, Which Face? Whose Nation?, 42 AMER. BeHAV. SCIENTIST 1314 (1999); Gerald L. Neuman, The Lost Century of American Immigration Law (17761875), 93 COLUM. L. REV. 1833 (1993).

73. Mark C. Weber, Opening the Golden Door: Disability and the Law of Immigration, $8 \mathrm{~J}$. Gender, RACE \& Just. 153 (2004). See also Douglas C. Baynton, Defectives in the Land: Disability and American Immigration Policy, 1882-1924, 24 J. AMER. ETHNIC HIST. 31 (2005) (discussing early immigration policy with regard to mental incapacity). 
perception of a threat to the public has tended to predominate over considerations of individual capacity. ${ }^{74}$ Mental health and capacity are like exclusions for criminals in this respect-historically, mental illness has been treated as a prediction of future threats to public safety, a less immediate threat than that of an imminent epidemic. These exclusions are also a prediction about the demand on social services to treat individuals.

I am not concerned here with the many current issues with respect to disability and U.S. immigration law, including due process concerns and the provision of counsel in removal proceedings for mentally disabled migrants. $^{75}$ These issues, along with refugee health, are of critical importance but are beyond the scope of the points I wish to make.

\section{A. The Long History of Mental Health Exclusions}

The history of health-based exclusions in the U.S. is not entirely new terrain. Particularly well covered in the historiography are the banishment of homosexuals, prostitutes, and the use of physical characteristics to exclude ethnic and racial groups, as well as the exclusion of persons based upon political belief. ${ }^{76}$ My purpose here is not to revisit this scholarship, but to contrast exclusion for contagious disease (the historical equivalents of Ebola) with non-contagious conditions. Today, we view many practices excluding immigrants to have been strikingly discriminatory, ${ }^{77}$ but exclusions directed to mental health and capacity are not viewed this way.

Local governments in the original thirteen states, and those that followed, routinely turned away nonresidents who were poor or disabled, including those with mental disabilities who were unable to support themselves. ${ }^{78}$ Excluding immigrants who may become a "public charge"

74. For commentary on current law excluding non-citizens based on danger posed by mental disorder, see Jennifer Blakeman, The Exclusion of Mentally Ill Aliens Who May Pose A Danger to Others: Where Does the Real Threat Lie?, 31 U. MiAMI INTER-AM. L. ReV. 287 (2000).

75. See, e.g., Alice Clapman, Hearing Difficult Voices: The Due-Process Rights of Mentally Disabled Individuals in Removal Proceedings, 45 NEW ENG. L. REV. 373 (2011).

76. See, e.g., Daniel Kanstroom, Deportation Nation: OUtSiders in AMERICAN History (2007); Hiroshi Motomura, AMERICANS IN WAiTING: The LOST STORY OF IMMIGRATION AND CiTiZENSHIP IN THE United STATES (2006), at 21-24, 39-40, and sources cited therein; Carol Leslie Wolchok, Aids at the Frontier: United States Immigration Policy, 10 J. LEGAL MED. 127, 128 (1989) (detailing U.S. history of excluding immigrants based on “'undesirable' medical infirmities or disabilities").

77. See, e.g., Samuel M. Silvers, The Exclusion and Expulsion of Homosexual Aliens, 15 COLUM. Hum. RTS. L. ReV. 295 (1984).

78. See Baynton, supra note 73, at 32; William P. Quigley, Reluctant Charity: Poor Laws in the 
has been a consistent feature of law in the U.S., and remains a ground of exclusion today. ${ }^{79}$

The U.S. Public Health Service, created by Congress in 1912 as a renamed version of the earlier Marine Hospital Service, ${ }^{80}$ had as its primary mission to prevent contagious diseases from entering the country via immigration and trade. ${ }^{81}$ Historically, state and local health authorities held complete inspection and quarantine authority at ports of entry and border crossings. ${ }^{82}$ Passengers and crew entering these ports were subject to detention for "suspicious sickness" on board or at the point of landing. ${ }^{83}$ Refusing entry to foreign ships - with passengers and crew-could be effected on the authority of a state or local health official. ${ }^{84}$ In modern practice, the federal Centers for Disease Control and Prevention has been tasked with the designation of "communicable disease[s] of public health significance," and the U.S. Public Health Service provides screening at ports of entry. ${ }^{85}$

Legislation by Congress permitting the exclusion of aliens on the basis of health or communicable disease dates back to the Immigration Act of 1891 . $^{86}$ "Persons suffering from a loathsome or a dangerous contagious disease" were added to the grounds of exclusion, and the 1891 Act also required a medical inspection of all aliens arriving at ports of entry. ${ }^{87}$ Other features of the law prohibited the immigration of "idiots" and "lunatics." 88 When the various immigration and citizenship

Original Thirteen States, 31 U. Rich. L. REV. 111, 111-12 (1997) (“Assistance ... was strictly rationed to those local residents considered worthy of help. Visitors, strangers and nonresident poor people were not helped and were legally run out of town.").

79. Immigration and Nationality Act $\S 212(a)(1)(A)(i), 8$ U.S.C. $\S 1182(a)(1)(A)(i)$ (2013) [hereinafter I.N.A.]. See also Neuman, supra note 72, at 1846-48 (describing poverty exclusions by state and local governments); Leo M. Alpert, The Alien and the Public Charge Clauses, 49 YALE L. J. 18 (1939) (providing historical context for "persons likely to become a public charge").

80. Act of Aug. 14, 1912, ch. 288, 37 Stat. 309 (repealed 1944). The U.S. Public Health Service was authorized in 1912, among other tasks, to "study and investigate the diseases of man and conditions influencing the propagation and spread thereof . . . and ... issue information in the form of publications for the use of the public." Id. § 1, 37 Stat. at 309.

81. Margaret Humphreys, Yellow FeVer and the South 69 (1992).

82. See Margaret Warner, Local Control Versus National Interest: The Debate over Southern Public Health, 1878-1884, 50 J. S. HIST. 407, 407-08 (1984).

83. See Treasury Department, ANNUAL Report of the Supervising Surgeon General 1681, available at https://archive.org/stream/annualreportofsu1901unit\#page/10/mode/2up.

84. See Warner, supra note 82 , at $407-08$.

85. History of Quarantine, CDC, http://www.cdc.gov/quarantine/HistoryQuarantine.html (last updated July 31, 2014).

86. 1891 Immigration Act, ch. 554, 26 Stat. 1084 (1891), available at library.uwb.edu/guides/usimmigration/26\%20stat\%201084.pdf.

87. Id.

88. Id. 
laws were unified and codified as the Immigration and Nationality Act of 1952 (INA), the health-related grounds were seven of 31 grounds for exclusion. ${ }^{89}$

Today, one of the reasons why a foreign national might be deemed inadmissible is on health-related grounds. Currently, "foreign nationals not already legally residing in the United States who wish to come to the United States generally must obtain a visa and submit to [a health] inspection to be admitted." 90

The modern iteration excludes persons with a "communicable disease of public health significance," as detailed in regulations promulgated by the Department of Health and Human Services. ${ }^{91}$ Persons with "physical or mental disorders" may also be excluded, if they are adjudged:

1. [T]o have a physical or mental disorder and behavior associated with the disorder that may pose, or has posed, a threat to the property, safety, or welfare of the alien or others, or

2. [T]o have had a physical or mental disorder and a history of behavior associated with the disorder, which behavior has posed a threat to the property, safety, or welfare of the alien or others and which behavior is likely to recur or to lead to other harmful behavior. ${ }^{92}$

Mental disorder as a disqualification for entering the U.S., and accordingly disqualification for U.S. citizenship, has a long history, points of which are noted below. So, too, the public perception of classes of immigrants considered "undesirable." A Senate report in 1950 concluded that foreign-born persons had higher rates of mental disease than the native population. ${ }^{93}$ There is ample evidence that this was a

89. Ruth Ellen Wasem, Immigration Policies and Issues on Health-Related Grounds for Exclusion, CONGRESSIONAL RESEARCH SERVICE, at 2 (2014), available at http://www.fas .org/sgp/crs/homesec/R40570.pdf.

90. Id. at 1 .

91. I.N.A. § 212(a)(1)(A)(i). The Department of Health and Human Services regulations at 42 CFR $\S 34.2(\mathrm{~b})$ define the term "communicable disease of public health significance" as including: (a) chancroid; (b) gonorrhea; (c) granuloma inguinale; (d) human immunodeficiency virus (HIV) infection; (e) leprosy, infectious; (f) lymphogranuloma venereum; (g) syphilis, infectious stage; and (h) tuberculosis, active. The CDC recently updated its Mental Health Technical Instructions used for diagnosis in immigration matters. See Technical Instructions for Civil Surgeons and Panel Physicians, CDC, http://www.cdc.gov/immigrantrefugeehealth/exams/ti/faq-physical-mental-disor ders-technical-instructions.html (last updated Dec. 5, 2013).

92. I.N.A. § 212(a)(1)(A)(iii) (formerly I.N.A. § 212(a)(1)(A)(ii)).

93. S. Rep. 81-1515, S. COMM. ON THE JUDICIARY, 81st CONG., REP. ON IMMIGRATION AND NATURALIZATION SYSTEMS OF THE UNited STATES (April 20, 1950), reprinted in OsCAR M. TRELLES AND JAMES F. BAILEY, IMMigRATION AND NATIONALITY ACTS: LEGISLATIVE HistorieS 
long-standing public belief, beginning with the first large waves of immigration in the latter nineteenth century.

I offer two brief observations before exploring this history further. First, immigrant health exclusions codified in federal legislation were not driven purely by public health concerns. Second, Congressional control of health-based exclusion categories sometimes bore no relationship to the scientific medical learning of the day. In the psychiatric field, reliance on agency implementation has been problematic, even as medical understanding of psychiatric disorders has changed over time.

\section{B. Immigrants and the Asylum, a Question of Who Pays}

State-run asylums for the mentally ill originated in the nineteenth century. There are many excellent histories of these institutions, usually with a focus on abusive treatment and the "warehouse" role to confine and segregate the mentally ill and disabled from the rest of society. ${ }^{94}$

Until the great waves of migration of the late nineteenth and early twentieth centuries, foreign birth was noted for asylum inmates but otherwise raised no concern for reimbursement for indigent non-citizens. One of the earliest and largest of such institutions was the Georgia State Lunatic, Idiot, and Epileptic Asylum, opened in 1842 and later named the Georgia State Sanitarium and the Milledgeville State Hospital. ${ }^{95}$ The asylum accepted both "pay" patients and paupers "sent here in conformity with the requisitions of the law." $" 96$ The asylum accepted patients regardless of nationality, although patient records usually noted the country of birth if not the United States. ${ }^{97}$ The patients were primarily German and Irish, ${ }^{98}$ reflecting migration patterns at that point in Georgia.

Patient records reveal how asylum medical staff regarded patients, especially reflecting the variety of diagnoses and speculation about presumed causes of a disorder. For example:

\footnotetext{
AND RELATED DocumentS, at 197 (1979-1981). Text of the Senate Judiciary report is available at https://bulk.resource.org/gao.gov/82-414/000022C1.pdf.

94. See, e.g., Michael T. Keene, Mad House: The Hidden History of Insane Asylums in $19^{\text {TH }}$-CENTURY NEW York (2013); Christopher PAYNe AND Oliver SACKS, ASYlum: InSIDE THE Closed World of State Mental Hospitals (2009).

95. See Peter G. Cranford, But for the Grace of God: Milledgeville! (1981).

96. Paul K. Graham, Admission Register of Central State Hospital, Milledgeville, GEORGIA, 1842-1861 (2011).

97. Id.

98. Id.
} 
Caleb Wilkerson, pauper, lunatic from Troup County, age 49, single, cause of lunacy, disappointed affection, duration 25 or 30 years, common laborer, came of his own accord on foot, without clothing to conceal his nakedness, shoes or hat, had not eaten more than twice or three times while on the road, although he was 5 or 6 days coming. Recd. him Feb 29th 1845, gave him clothing \&c., \& wrote the Justices of the Inferior Court of his arrival who promised to have him legally committed. They neglected to do so until the 13th May 1846 at which time he was turned out. He then made application in person to the Justices of the Inferior Court of this county for commitment to the asylum which commitment was granted 23rd May 1846 at which time he was recd. as a pauper. ${ }^{99}$

Although foreign birth was often seen as a factor in mental illness, in these early asylum cases there is no indication that the institutions themselves refused admission to non-citizens, or that they sought reimbursement specifically for housing and treating recent immigrants. The citizenship of an inmate seems to have been noted for its potential as a factor in diagnosis, rather than fear of immigrant traits or significance for payment. One record, for example, links nationality to a suspected cause of "insanity":

Jacob Keener, pauper patient from Troup County, German, occupation cabinet workman, age [blank] years, duration of insanity [blank] years, cause unknown except it be an ardent desire to return to Germany with inability to do so.

Another patient record noted the patient was "an Englishman" but did not specify any link to his condition, reportedly that he was "badly insane." $" 101$

This relative lack of concern with immigration status would change with growing numbers of immigrants, together with a perception that these new immigrants came from inferior stock. Other nations, some

99. Id. at 5. For another example, one patient record stated: “Anderson Quick, pauper, lunatic from Fayette County, age 26, single, laborer, insanity caused by solitary confinement, duration 8 years, was chained to one spot during the whole period, admitted 28th June 1846, died of marasmus 11th May 1847." Id. at 11.

100. Id. at 72 .

101. "John Wade, lunatic, pauper from Savannah, age 36, married, engineer and machinist, Englishman, cause of insanity ill health and jealousy, duration two years, admitted 11th April 1844, discharged 4th July 1844, on promise that he would leave the state. He visited several of the western states, some of the northern states, and finally went to Savannah. They supposed there that he had escaped from the institution. He was immediately arrested and returned to the asylum without any form of commitment August 26th 1845. He remained here till the 16th December 1845 at which time he made application to the board of trustees for a discharge. They determined that they had no legal right to withhold it and it was granted. When last heard from he was in Charleston at work in a machine shop, still badly insane." Id at 2 . 
believed, used America's liberal immigration policies to rid themselves of undesirable persons - the poor, the uneducated, and the physically and mentally inferior.

Beginning in the twentieth century, state governments played a limited role in mental health-based exclusions for immigrants, and this role was primarily to identify non-citizens for deportation on the ground that they had become a "public charge." The key for this development was the concept of "delayed exclusion" in federal immigration law, which allowed deportation of a non-citizen who had been living in the United States but who had been "overlooked" in the federal medical exam process at the port of entry. ${ }^{102}$ Initially, delayed exclusion was possible after one year of entry; soon the limitation period expanded to two years, and finally to five years following entry. ${ }^{103}$ Once post-hoc inadmissibility was possible, it became a common practice for state health agencies and hospitals - especially mental health institutions - to engineer the deportation of any non-citizen who had become a public charge or who had spent even a small amount of time in a mental institution. ${ }^{104}$

The McCarran-Walter Immigration Act of 1952 continued this retroactive exclusion as federal law, providing for the deportation of foreign nationals who were excludable at time of entry if they later became a public charge or were "persons afflicted with psychopathic personality." $" 105$

The Yale Law Journal examined the mental health ground in 1959 in an article entitled "Limitations on Congressional Power to Deport Resident Aliens Excludable as Psychopaths at Time of Entry." "106 While the article criticized administrative expulsion because of the indefinite standard government officials used, it also pointed out that most expulsion cases came at the request of state health officials and were based solely upon a medical certificate or record of a hospital stay. ${ }^{107}$

102. See generally KANSTROOM, supra note 76, at 124-27 (describing development of post-entry social controls, including exclusion for crimes committed after entry).

103. Thomas AleXander Aleinikoff et al., Immigration and Citizenship: Process and POLICY 771-772 (6th ed. 2008).

104. See Amy L. Fairchild, Policies of Inclusion: Immigrants, Disease, Dependency, and American Immigration Policy at the Dawn and Dusk of the 20th Century, 94 AM. J. PuB. Health 528 (2004), available at http://www.ncbi.nlm.nih.gov/pmc/articles/PMC1448289/pdf/0940528.pdf.

105. McCarran-Walter Act of 1952, H.R. 13342, 82nd Cong. (1952) available at http://wwwrohan.sdsu.edu/dept/polsciwb/brianl/docs/1952McCarranWaltersAct.pdf.

106. Note, Limitations on Congressional Power to Deport Resident Aliens Excludable as Psychopaths at Time of Entry, 68 YALE L. J. 931 (1959).

107. Id. 
The U.S. Public Health Service frequently relied upon state medical evaluations with only a cursory stamp of approval - having never met or evaluated the patient-because they lacked the staffing to follow-up individual cases. One example was the case of Mrs. Margarita Leon, a patient committed to a state mental hospital in 1951 following an altercation in which she struck a bartender with a bottle. ${ }^{108}$ She was found deportable by federal immigration authorities on the ground that she was afflicted with "constitutional psychopathic inferiority" at the time she entered the country two years earlier. ${ }^{109}$ The evidence was based on a medical certificate and the following history:

Patient was a problem in childhood, eloped from school with a man at age of 15 , has had two divorces and has lived without marriage with a man for the past nine years, except for brief interval when she married and deserted husband. Described by others as unreliable, untruthful, intemperate, quarrelsome, and bad tempered.

Mrs. Leon's story compellingly illustrates the primacy of the state role and the acquiescence of federal health and immigration officials. Following Mrs. Leon's two-week involuntary commitment at Bellevue, she subsequently was transferred to another New York state mental facility where she was a patient for five months. ${ }^{111}$ During this time New York state officials contacted federal immigration authorities, reporting that Mrs. Leon was not a citizen and had been diagnosed by them as having "psychosis with psychopathic personality; paranoid trends." 112

As Mrs. Leon's case wound its way through federal deportation proceedings, she sought and obtained an examination by a U.S. Public Health Service medical officer. ${ }^{113}$ That officer concluded that at the time of his examination, there was "no evidence of overt psychosis." Nonetheless, the officer concluded there was "no doubt that the patient was properly certified as suffering from constitutional psychopathic inferiority at the time of her entry," meaning she should have been certified as mentally unfit five years previously. ${ }^{115}$ The medical officer's conclusion was based entirely upon mental health records provided by

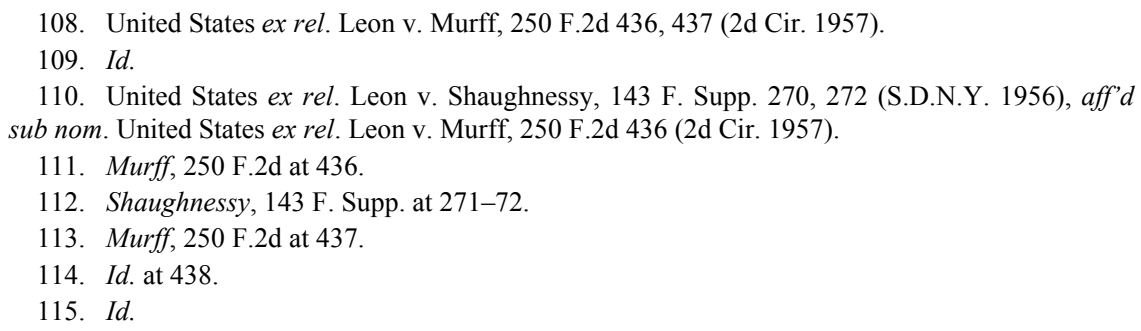


the state of New York. ${ }^{116}$ That she came to the attention of federal immigration officers at all was entirely at the instance of the hospital's medical staff. ${ }^{117}$

While state officials alerted immigration authorities about persons excludable for public charge and other health-related grounds, "mental defect" seems to have been the most common charge. It was also quite vague and subject to abuse which neither the Public Health Service nor the Board of Immigration Appeals was willing to remedy. As Judge Learned Hand wrote in 1959, deportation was legally permitted for persons "who by nature were subject to insanity of one sort or another; that is to say, whose constitution was such that they had not normal mental stability ... inherent in their nervous structure."118 Courts, Hand wrote, "must accept the opinion of those formally qualified" to make such pronouncements. "The whole subject is one of excessive uncertainty at best; whoever is fitted for the responsibility, it is certain that we are not; we must act upon what those tell us who carry the proper credentials." 120

To its discredit, the U.S. Public Health Service adopted the same attitude with respect to state certifications of mental disability. ${ }^{121}$ Responding to criticisms that "psychopathic personality" was "the most disputed and open-ended diagnostic label in the field of psychiatry,"122 the Public Health Service issued regulations effective in 1948 that provided:

There shall be certified as cases of constitutional psychopathic inferiority all psychopathic characters such as "chronic litigants," "sexual perverts," "pathological liars," "dipsomaniacs," "moral imbeciles" and mentally peculiar persons who because of eccentric behavior, defective judgment, or abnormal impulses are in repeated conflict with social customs and constituted authorities. ${ }^{123}$

\footnotetext{
116. Id. at $437-39$.

117. Id.

118. United States ex rel. Powlowec v. Day, 33 F.2d 267, 268 (2d Cir. 1929).

119. Id.

120. Id.

121. One historian claims that U.S. P.H.S. physicians refused to sit on these "Boards of Special Inquiry," as an explanation for the fact physicians did not participate in final decisions to admit or deport. See Alan M. Kraut, Germs, Genes, and American Efficiency, 1890-1924, 12 Soc. SCI. HISTORY 377, 385 (1988).

122. Limitations on Congressional Power, supra note 106, at 940.

123. Id. at $940-41$.
} 
The Public Health Service attempted to provide national standards for "constitutional psychopathic inferiority," but the broad categories left ample room for unchecked discretion and abuse by both state and federal medical officials.

State officials desired to rid themselves of "undesirable" non-citizens housed in state institutions. The solution was to deport these undesirables. In 1926, for example, 796 persons were deported for "insanity" or "epilepsy," 257 for "other mental conditions," and 887 as "likely to become a public charge," out of nearly 11,000 total deportations that year. ${ }^{124}$ Similar categorical deportation numbers occurred in $1930 .{ }^{125}$ In later decades the bases for deportation are not categorized, but we know the practice continued because of cases like that of Mrs. Leon. ${ }^{126}$

This brief history provides some illustration of the link between becoming a "public charge" and the social control of the "undesirable" immigrant. There was little if any change over time in the views of federal lawmakers. Congress feared that a liberal immigration policy encouraged other nations to export their own undesirable citizens. Congress also made possible reciprocal "dumping" by the United States. Persons with mental illness or disability were the prime targets of this form of foreign policy. A later era would experience this first-hand. In the early 1980 s, Cuba sent nearly 125,000 residents to the U.S., including an allegedly large number of convicts and mentally ill individuals, and refused to take them back. ${ }^{127}$

\section{Landmarks in Congressional Debate: Reciprocal "Dumping" as Foreign Policy}

On two notable occasions in the past, Congress has focused specifically on mental health exclusions of immigrants. First, in 1911, Congress intensively studied the U.S. immigration system through a series of commissioned reports, with an important focus on excluding the "undesirable" immigrant. Then, prior to the major overhaul of the immigration system in the McCarren-Walter Act of 1952, Congress

124. Jane Perry Clark, Deportation of Aliens from the United States to Europe 14 (1968).

125. Id. In 1930, 509 persons were deported for "Insanity, epilepsy," 221 for "other mental conditions," and 305 as "likely to become a public charge." Id.

126. See supra notes 106-115 and accompanying text.

127. See Maria V. Morris, The Exit Fiction: Unconstitutional Indefinite Detention of Deportable Aliens, 23 Hous. J. INT’L L. 255, 297 (2001). 
produced an extensive legislative history, revisiting many of the issues of the 1911 study. In both instances, screening for the mental health of immigrants received specific attention. Both also reflect the prevailing belief that other nations were "exporting" mentally ill and disabled persons to the United States. State and local governments bore this burden, resulting in significant pressure on the federal government to accommodate their interests.

\section{The Dillingham Commission}

In 1907, Congress commissioned what became known as the Dillingham Commission, named after its chairman, Senator William Dillingham, to study the subject of immigration. ${ }^{128}$ At that time, around one million immigrants per year, mostly from Southern and Eastern Europe, entered the United States through Ellis Island. ${ }^{129}$ The reports of the joint House-Senate commission, published in 42 volumes, contrasted old world and new world immigration, a subject that was the focus of eugenic concerns. ${ }^{130}$ Among other proposals, the Commission recommended literacy tests and racial quotas geared towards reducing the number of undesirable entrants. ${ }^{131}$ Congress adopted many of the Commission's recommendations in $1917 .{ }^{132}$ These new immigrants were more readily viewed as "undesirable," compared to prior immigrants from northern Europe. ${ }^{133}$

The Commission's work had a significant influence on subsequent legislation:

128. See Rachel Silber, Note, Eugenics, Family \& Immigration Law in the 1920's, 11 Geo. IMMIGR. L.J. 859, 867-68 (1997) (describing work of the Dillingham Commission).

129. See U.S. IMMIGRATION COMM'N, REPORTS OF THE IMMIGRATION COMMISSION: Statistical ReVieW Of IMMigRation 1820-1910, S. Doc. No. 756, at 4 (3d Sess. 1911).

130. See Jeanne D. Petit, The Men and Women We Want: Gender, Race, and the Progressive ERA Literacy Test Debate 6-7 (2010); Silber, supra note 128, at 867; Martin S. Pernick, Eugenics and Public Health in American History, 87 AM. J. PUB. HeAlth 1767, 1767 (1997); John M. Lund, Boundaries of Restriction: The Dillingham Commission, 6 U. VT. HIST. ReV. (Dec. 1994), available at http://www.uvm.edu/ hag/histreview/vol6/lund.html; A. J. McLaughlin, Immigration and the Public Health, 29 PUB. HEALTH PAPERS \& REP. 224, 224 (1903), available at http://www.ncbi.nlm.nih.gov/pmc/articles/PMC2222384/pdf/pubhealthpap00008-0229.pdf ("With the change in the racial character of immigration, most marked in the past decade, a pronounced deterioration in the general physique of the immigrants, and a much higher percentage of loathsome and dangerous diseases is noticeable.").

131. Richard A. Boswell, Crafting an Amnesty with Traditional Tools: Registration and Cancellation, 47 HARV. J. ON LEGIS. 175, 180 n.23, 182 (2010).

132. Id. at $180-82$.

133. Anna O. Law, Race, Ethnicity, and National Origins in Public Policy-When Should It Matter?, 10 GeO. IMMIGR. L.J. 71, 73 (1996). 
The commission's overall findings provided the rationale for the politically and economically inspired immigration restriction acts of the 1920s, including the Emergency Quota Act of 1921, which favored immigration from northern and western Europe by restricting the annual number of immigrants from any given country to 3 percent of the total number of people from that country living in the United States in 1910. The movement for immigration restriction that the Dillingham Commission helped to stimulate culminated in the National Origins Formula of 1929, which capped national immigration at 150,000 annually and barred Asian immigration altogether. ${ }^{134}$

Volume Two of the reports included the topic, "Immigration and Insanity." 135 It began with an overview of prior and current legislation on the subject:

Foreign-born persons of unsound mind have been excluded from the United States by federal legislation since 1882. The law of 1882 prohibited the immigration of idiots and lunatics, and that of 1891 excluded idiots and insane persons. The statutes since enacted have been more comprehensive in their terms. In 1903 a law was passed prohibiting the immigration of idiots, insane persons, persons insane within five years of the date of application for admission, and persons having had two or more previous attacks of insanity. The law of 1907 excludes idiots, imbeciles, feeble-minded persons, persons insane within five years of the date of application for admission, persons having had two or more previous attacks of insanity, and persons suffering from mental defects, not otherwise specified, sufficiently serious to affect ability to earn a living. ${ }^{136}$

The report noted that under these statutes, "many aliens have been excluded," and warned of a "very marked increase in the number of persons prevented, by reason of mental diseases, from entering the United States." 137 The report also provided a statistical breakdown of immigrant exclusions or deportations since 1890, divided into six categories: "Lunatics," "Insane," "Idiots," "Idiots and insane," "Imbeciles," and "Feeble-minded." 138

The commission claimed that despite efforts of immigration officials, there were "at the present time a large number of mentally unsound

134. Dillingham Commission (1907-1910), Harv. U. LiBr. Open Collections Program, http://ocp.hul.harvard.edu/immigration/dillingham.html (last visited Mar. 31, 2015).

135. U.S. IMMIGRATION COMM'N, REPORTS OF THE IMMIGRATION COMMISSION: ABSTRACTS OF REPORTS OF THE IMMIGRATION COMMISSION, VOL. II, S. DOC. NO. 747, at 223 (3d Sess. 1911).

136. Id. at 227 (citations omitted).

137. Id. at $227-28$.

138. Id. at 227 . 
aliens" residing in the United States. ${ }^{139}$ Of special note were non-citizens confined in state asylums and charity hospitals, classified both by race and country of birth. ${ }^{140}$ Of these, the report states, "it is evident that the foreign born continue to furnish much more than their proportionate share of insane." 141

For the possible causes of "high ratios of insanity among the foreignborn," the report identified the primary cause to be inefficiency of federal immigration enforcement:

As has been stated, the immigration of mentally unsound aliens is prohibited by law. Any failure in the enforcement of this law would of course tend to result in the admission to the United States of mentally diseased persons and in a corresponding increase in the number of foreign-born insane in the country. On the other hand, racial traits or tendencies, as shown by the ratios of insanity in the countries from which the immigrants came, may be responsible, to a certain extent, for the relative prevalence of insanity among the foreign-born population of the United States. It is possible also that the tendency to insanity among the immigrants of the different nationalities is increased by the change in environment occasioned by immigration.

Not surprisingly, the Commission's recommendations did not propose any change to the statutory exclusions, but said that more effective methods of screening were needed: "[T]he enforcement of such provisions is doubtless as satisfactory as can be expected in view of conditions under which arriving immigrants must be inspected."143

Ultimately, Congress adopted the following language in 1917:

That the following classes of aliens shall be excluded from admission into the United States: All idiots, imbeciles, feeble-minded persons, epileptics, insane persons; persons who have had one or more attacks of insanity at any time previously; persons of constitutional psychopathic inferiority; persons with chronic alcoholism; paupers; professional beggars; vagrants; persons afflicted with tuberculosis in any form or with a loathsome or dangerous contagious disease; persons not comprehended within any of the foregoing excluded classes who are found to be and are certified by the examining surgeon as being

139. Id. at 229 .

140. See id. at $230-33$.

141. Id. at 235 .

142. Id. at 245 .

143. Id. at 251 . 
mentally or physically defective, such physical defect being of a nature which may affect the ability of such alien to earn a living ....

The reports of the Dillingham Commission both reflected and set the tone for debate in Congress concerning the "undesirable" immigrant with mental illness. ${ }^{145}$ Forty years later, Congress took another close look at mentally disabled immigrants.

\section{Legislative History of the 1952 McCarran-Walter Immigration Act}

Beginning in 1950, a subcommittee of the Senate Committee on the Judiciary conducted a comprehensive study of the immigration laws, much like the Dillingham Commission had done four decades earlier. Many of the concerns presented in the Dillingham report also appear in the 1950 report that served as the foundation for the McCarran-Walter Act of 1952. ${ }^{146}$ That legislation, The Immigration and Nationality Act of 1952, has been amended in parts but is the primary law of immigration for the United States. ${ }^{147}$

In general, the classes of undesirable aliens retained in the bill were made more definite, including medical grounds for exclusion. The 1917 Act, as we have seen, excluded "persons of constitutional psychopathic inferiority." "148 The 1952 Act modified the 1917 Act's provisions to exclude "[a]liens afflicted with psychopathic personality, epilepsy or a mental defect."149

144. Immigration Act of 1917, ch. 29, 39 Stat. 875 (1917) (emphasis added), available at http://library.uwb.edu/guides/usimmigration/39\%20stat\%20874.pdf.

145. Compare the following excerpt from a Senate report on the proposed Immigration Act of 1917:

The reasons for excluding a physically defective alien are likelihood of his becoming a public charge and inability by his own exertions to care for himself and those dependent upon him, while the real object of excluding the mentally defective is to prevent the introduction into the country of strains of mental defect that may continue and multiply through succeeding generations, irrespective of the immediate effect thereof on earning capacity. This change was made only after consultation with persons of knowledge and experience, and is in line with the well-established public policy of rigidly excluding the mentally deficient.

S. REP. No. 64-352, at 5 (1916).

146. Pub. L. No. 82-414, 66 Stat. 163 (1952). See S. ReP. No. 81-1515, at 805 (1950).

147. The Immigration and Nationality Act is codified under Title 8 of the United States Code, 8 U.S.C. § 1101-1537 (2012).

148. Immigration Act of 1917, supra note 144, at 875.

149. Immigration and Nationality Act, 66 Stat. 163, 182 (1952); I.N.A. § 212(a)(4); 8 U.S.C. § 1182(a)(4) (1952) (amended 1990). 
A committee report states that those grounds were re-examined based upon information provided by the Public Health Service. ${ }^{150}$ The Surgeon General wrote:

Members of the committee are undoubtedly aware of the difficulties under which the medical examination of aliens is performed. Occasionally, applicants attempt to conceal from the examining physician evidence which might result in their exclusion from the United States. From time to time we hear of a visa applicant with a medical disability who has undergone treatment and received instructions from a private physician to help conceal the disability from the examining medical officer. Under these circumstances it may be difficult, or even impossible, to detect mental conditions such as psychopathic personality, sexual deviation, or drug addiction. In connection with your committee work in redrafting the medical aspects of the Immigration Act, the enclosed Manual for Medical Examination of Aliens and the medical examination form may be of interest. ${ }^{15}$

Other Congressional reports focused specifically on the language used for mental health exclusions. The Public Health Service contributed a lengthy report in which it recommended the exclusion of one term:

The use of the expression "feeble-mindedness," unless intended to be all-inclusive, is inappropriate. Feeble-mindedness is an inclusive generic term represented by subclasses of idiots, imbeciles, morons, and borderline intelligence. Any degree of feeble-mindedness falls within the specific subclasses of idiocy, imbecility, moron, and borderline intelligence. There is no point in retaining the inclusive generic term "feeble-minded." It should be deleted from the language of the bill and replaced by the definitive terms just listed. It is suggested that a more appropriate wording would be as follows: "Aliens who are idiots, imbeciles, or morons."

The most controversial term, as it would emerge, was the substitution of "psychopathic personality" for "constitutional psychopathic inferiority":

Although the term "psychopathic personality" used in classifying certain types of mental disorders, is vague and indefinite, no more appropriate expression can be suggested at this time. The conditions

150. H.R. REP. NO. 82-1365 (1952), reprinted in 1952 U.S.C.C.A.N. 1653, 1698-99.

151. Id. at 1699 .

152. Id. at 1700 (citing to Report of The Public Health Service on the Medical Aspects of H.R. 2379, A Bill to Revise the Laws Relating to Immigration, Naturalization, and Nationality, and for Other Purposes). 
classified within the group of psychopathic personalities are, in effect, disorders of the personality. They are characterized by developmental defects or pathological trends in the personality structure manifest by lifelong patterns of action or behavior, rather than by mental or emotional symptoms.... Until a more definitive expression can be devised, the term "psychopathic personality" should be retained.

A few years after enactment, an article in the Yale Law Journal attacked the new standards for determining mental incompetency introduced by the Act:

The McCarran Immigration Act's provision for the deportation of aliens who were excludable at time of entry as "persons afflicted with psychopathic personality" permits administrative expulsions under an indefinite standard to which the courts have added scant precision. As a result, unpredictable and largely uncontrolled deportations effecting "delayed exclusion" may occur at the order of immigration hearing officers. ${ }^{15}$

The U.S. Supreme Court drew extensively on this legislative history when it held in Boutilier v. Immigration and Nationalization Service that an alien who was a homosexual was "afflicted with psychopathic personality" within the terms of the 1952 Act, and thus was excluded from admission. ${ }^{155}$ This case became a flashpoint of debate concerning the treatment of homosexuals, a debate that extended to subsequent exclusions based on HIV status. ${ }^{156}$ As one scholar noted, "The exclusion of homosexuals has been, by far, the most controversial application of the mental defect and disability exclusion." ${ }^{\prime 57}$ A perfect illustration, if one were needed, of why it is hazardous to view "mental illness" as a fixed set of conditions.

The case was based upon an affidavit submitted by the Public Health Service stating that in the opinion of the diagnosing physicians, the

\footnotetext{
153. Id.

154. Limitations on Congressional Power, supra note 106, at 931 (internal citations omitted).

155. 387 U.S. 118, 122 (1967).

156. See generally Kevin R. Johnson, The "Huddled Masses" Myth: Immigration and CIVIL Rights 140-51 (2004) (noting that the Supreme Court rejected several constitutional challenges to the classification of homosexuals attempting to enter this country as psychopathic personalities, leading lives of sexual deviation); Robert Foss, The Demise of the Homosexual Exclusion: New Possibilities for Gay and Lesbian Immigration, 29 HARV. C.R.-C.L. L. REV. 439, 447-50 (1994) (summarizing the socio-political background of the homosexual exclusion); Lyn G. Shoop, Comment, Health Based Exclusion Grounds in United States Immigration Policy: Homosexuals, HIV Infection and the Medical Examination of Aliens, 9 J. CONTEMP. HeAlth L. \& POL'Y 521, 527-28 (1993) (describing the evolution of the exclusion).

157. Shoop, supra note 156 , at 527 .
} 
"petitioner was afflicted with a class A condition, namely, "psychopathic personality, sexual deviate' at the time of his admission." "158

The Court recounted the legislative history of the 1952 Act to support its conclusion that a homosexual could be classified as having a "psychopathic personality." The passage is worth quoting at length:

The resulting legislation was first introduced as S. 3455 and used the new phrase "psychopathic personality." The bill, however, contained an additional clause providing for the exclusion of aliens "who are homosexuals or sex perverts." As the legislation progressed... however, it omitted the latter clause "who are homosexuals or sex perverts" and used only the phrase "psychopathic personality.",159

How is the omission explained? The Court relied on a brief paragraph in the Judiciary Committee's report:

The provisio(n) of S. 716 (one of the earlier bills not enacted) which specifically excluded homosexuals and sex perverts as a separate excludable class does not appear in the instant bill. The Public Health Service has advised that the provision for the exclusion of aliens afflicted with psychopathic personality or a mental defect which appears in the instant bill is sufficiently broad to provide for the exclusion of homosexuals and sex perverts. This change of nomenclature is not to be construed in any way as modifying the intent to exclude all aliens who are sexual deviates. ${ }^{160}$

The Court noted that the meaning of the term was hotly disputed among the medical community: "It may be, as some claim, that 'psychopathic personality' is a medically ambiguous term, including several separate and distinct afflictions. But the test here is what the Congress intended, not what differing psychiatrists may think." 161

A dissenting opinion believed the term to be hopelessly ambiguous: "The term 'psychopathic personality' is a treacherous one like 'communist' or in an earlier day 'Bolshevik.' A label of this kind when freely used may mean only an unpopular person. It is much too vague by constitutional standards for the imposition of penalties or punishment."162

158. Boutilier, 387 U.S. at 120 .

159. Id. at 121.

160. Id. (quoting S. REP. NO. 82-1137, at 9 (1952)).

161. Id. at 124 (emphasis added) (citation omitted). The Court adopted this nearly identical phrasing from a Fifth Circuit opinion a few years earlier: "Whatever the phrase "psychopathic personality' may mean to the psychiatrist, to the Congress it was intended to include homosexuals and sex perverts." Quiroz v. Neelly, 291 F.2d 906, 907 (5th Cir. 1961).

162. Boutilier, 387 U.S. at 125 (Douglas, J., dissenting). The dissent also cited to a medical text defining "psychopathic personality" as one who has the following characteristics: 
The equation of homosexuality with mental illness overshadows the general categorical exclusion, at least in recent scholarship. What was the role of the Public Health Service more broadly, in advising Congress on mental conditions and disabilities? As noted above, the Public Health Service suggested how they would interpret the proposed statutory language in the 1952 Act when evaluating immigrants applying for admission. But if the Public Health Service's proposed categories were insufficiently broad, it also suggested that a "catch-all" provision of mental defect would provide ample administrative discretion to exclude undesirable immigrants:

The term "mental defect," although broad and sweeping, is a safeguard for classifying those aliens who would not fit into the categories listed above. For example, there is a fairly large group of hereditary disturbances which at the time of examination could not be included in the above classification. ... Such a term could also be used to cover the more severely disabling neuroses and conduct and habit disorders of adults and children. It can be used in classifying those persons who are likely to be brought into repeated conflict with social customs, authority, or society in general. It is, therefore, recommended that the expression "as having a mental defect" be retained within the language of the bill. ${ }^{163}$

On the specific issue of homosexuality as "psychopathic," in 1979 the Surgeon General announced that homosexuality would no longer be considered a mental disease or defect. As a result, the Surgeon General "advised INS officers to stop referring aliens to the PHS for mental examinations solely to determine whether they were homosexuals."

Thus, political control of the Public Health Service has been a longstanding feature of its role in certifying non-citizens for admission. This political control, in turn, derives from what the modern federal courts

(1) Superficial charm and good 'intelligence.' (2) Absence of delusions and other signs of irrational 'thinking.' (3) Absence of 'nervousness' or psychoneurotic manifestations. (4) Unreliability. (5) Untruthfulness and insincerity. (6) Lack of remorse or shame. (7) Inadequately motivated antisocial behavior. (8) Poor judgment and failure to learn by experience. (9) Pathologic egocentricity and incapacity for love. (10) General poverty in major affective reactions. (11) Specific loss of insight. (12) Unresponsiveness in general interpersonal relations. (13) Fantastic and uninviting behavior with drink and sometimes without. (14) Suicide rarely carried out. (15) Sex life impersonal, trivial and poorly integrated. (16) Failure to follow any life plan.

Id. at 125-26 (citing HeRVEY M. CleCKLEy, THe MASK OF SANity: AN ATTEMPT TO ClaRify Some Issues About the So-CAlled Psychopathic Personality 238-55 (1941)).

163. H.R. REP. NO. 82-1365 (1952), reprinted in 1952 U.S.C.C.A.N. 1653, 1701.

164. In re Longstaff, 716 F.2d 1439, 1444 (5th Cir. 1983). 
still recite: "Congress has unbounded power to exclude aliens from admission to the United States."

What is the situation today? U.S. immigration law authorizes the exclusion of persons with "a mental disorder" if there is some reason to believe that an individual may pose a threat to public safety. Whether or to what extent this ground of exclusion is used today is difficult to discern. Neither the Public Health Service nor U.S. Citizenship and Immigration Services release data for persons excluded on the basis of a mental disorder. Other grounds of exclusion can be invoked insteadfor example, that an immigrant is likely to become a public charge, is a past drug user or alcoholic, or has a history of encounters with law enforcement or criminal incidents. ${ }^{166}$ Moreover, U.S. consular officers have essentially unreviewable discretion to issue visas.167 The lengthy process for a Green Card, for example, requires an in-person interview, a background check, and written answers to questions including:

"Have you ever been declared legally incompetent, or been confined to a mental institution?"

"Have you ever been placed in ... a rehabilitative program?"

"Have you ever . . . been a habitual drunkard?"168

While we do not know the extent to which immigration officials today exclude non-citizens on mental health grounds, Congress has maintained exclusions for mental illness even while it has eased nearly all restrictions based on physical disability.

165. Fernandez v. U.S. Immigration Dep't, No. 3:01-CV-0318-L, 2001 WL 460863, at*2 (N.D. Tex. Apr. 30, 2001) (citing In re Longstaff, 716 F.2d at 1442), report and recommendation adopted, No. CIV. A. 301CV0318L, 2001 WL 609742 (N.D. Tex. May 31, 2001).

166. These excludable grounds are found in I.N.A. § 212 and 8 U.S.C. $\S 1182$ (2012). In addition, an applicant for naturalization must show "good moral character." According to the USCIS Policy Manual, good moral character is defined as "character which measures up to the standards of average citizens of the community in which the applicant resides." U.S. Citizenship and Immigration Services, Policy Manual, v. 12, ch. 1, http://www.uscis.gov/policymanual/ HTML/PolicyManual-Volume12-PartF-Chapter1.html (last visited May 25, 2015).

167. In October 2014, the U.S. Supreme Court agreed to hear a case challenging the doctrine of consular non-reviewability - the availability of federal court review of visa denials. Din v. Kerry, 718 F.3d 856 (9th Cir. 2013), cert. granted, 135 S. Ct. 44 (2014) (granting petition for writ of certiorari with No. 13-1402).

168. See Application for Naturalization, Form N-400, U.S. CitizenshiP \& IMMigRATION SERVS., at 13, 15, 16, available at http://www.uscis.gov/sites/default/files/files/form/n-400.pdf. 


\section{CONCLUSIONS}

With established interests to protect, the United States along with every other nation imposes constraints on citizenship and migration by self-selection. What I have shown here is that the screen of "health security" is used to cover policy choices-whether to assume the risk of successfully managing contagious disease; whether to assume the burden of managing mental illness - that have shaped immigration policy for more than a century. The foremost difference is that contagious disease presents a verifiable condition, where mental illness has been defined in such hazy terms as to be applicable to just about anyone- or at least, as Justice Douglas argued, anyone "unpopular."169

Excluding immigrants on health grounds is problematic, especially if the health condition can be cured or the potential of spreading it to others can be minimized or eliminated. Exclusion based on mental conditions and disability can also be accommodated, but mental illness bleeds into fear of the criminal element as well as the public charge concern if a person is unable to work for self-support. A related concern is that excluding classes of migrants that are considered undesirable becomes a matter of foreign policy. As I have shown, the United States has at times viewed its health-based exclusions to be defensive in nature, warding off intentional export of undesirables by other countries. Whether or to what extent U.S. deportation practices have accomplished the same result is not explored here.

Can we envision a set of future circumstances in which an underdeveloped country suffering an epidemic will try to offload its patients on the United States or another developed country because of the treatment facilities available? Or the incident described earlier of the Mariel boatlift, in which a country attempts to export its undesirable citizens, including those with mental illness or disabilities? If so, we need to consider the obstacles, or the best avenues, for development of multi-national policy that can focus more on treatment and less on nationalistic "health security." Especially with mental health exclusions, is it possible to develop standards for dealing with mental illness that are comparable to standards regarding contagion? Although contagious disease and mental illness are substantially different, they share the same

169. As Justice Douglas wrote in his dissent in Boutillier, "A label of this kind when freely used may mean only an unpopular person." Boutilier v. Immigration \& Naturalization Serv., 387 U.S. 118, 125 (1967) (Douglas, J., dissenting). 
primary hurdle, which is the effort to appeal to humane consideration rather than the fear of the imperfectly-known. 